\title{
Cytologic Changes of Cervical Cancer According to the Degree of Invasion
}

\author{
Akira Yajima, Kensaku Teshima* and Kinchiro Noda* \\ Department of Obstetrics and Gynecology, Tohoku University \\ School of Medicine, Sendai 980 and *Department of Obstetrics \\ and Gynecology, Kinki University School of Medicine, Osaka \\ 589
}

Yajima, A., Teshima, K. and Noda, K. Cytologic Changes of Cervical Cancer According to the Degree of Invasion. Tohoku J. exp. Med., 1978, 126 (3), 295-299 - Cellular samples (cervical scrapings) obtained with wooden spatulas from patients with carcinoma in situ, early invasive cancer, and advanced cancer of the uterine cervix were examined. The number of malignant cells in the preparation increased with extent of the lesion. The granular chromatin structures of the nuclei of abnormal cells were observed in almost all cases, and the occurrence of irregularly distributed coarsely granular chromatin increased gradually with the extent of the cancer. Hyperchromasia of malignant cell nuclei and irregular thickening of the nuclear envelope were seen in almost all cases of the lesions. The occurrence of malignant and dysplastic cells of the deep layer types decreased with progression of the lesion from carcinoma in situ to early invasive cancer, and to advanced cancer. There was also a relative increase in the ratio of malignant cells to dysplastic cells.___uterine cervix; dysplastic cells; malignant cells

The cytodiagnostic technique is indispensable for the detection of uterine cervical cancer, especially for the detection of asymptomatic carcinoma in situ and early invasive cancer. In this study, comparative numerical analyses of cytologic findings were performed in cases of carcinoma in situ, early invasive cancer and advanced cancer to determine whether numerical analyses of cell findings may produce indications as to the morphologic extent of cervical lesions.

\section{Materials and Methods}

Patients for this study were selected in a mass screening project for uterine cancer, carried out in Miyagi Prefecture. Cellular samples were obtained from 86 patients with carcinoma in situ, 91 with early invasive cancer (stromal invasion within $5 \mathrm{~mm}$ ), and 50 with advanced cancer. The histologic specimens were obtained from eight block semiserial sections of the post-operative uterine cervix. Microscopic observations were performed to determine (a) the number of malignant cells and dysplastic cells, (b) the nuclear patterns of malignant cells, and (c) background of the preparations, especially the incidence of appearance of cellular detritus (tumor diathesis). Cellular samples were obtained with wooden spatulas from endocervix and ectocervix, and stained according to the Papanicolaou method.

Received for publication, April 18, 1978. 


\section{Results}

Cytologic observations of carcinoma in situ, early invasive cancer and advanced cancer

Cytologic findings of carcinoma in situ, early invasive cancer, and advanced cancer are shown in Table 1. As the cervical lesions progressed from carcinoma in situ to advanced cancer, nuclear chromatin tended to be more granular with irregular distribution. At the same time, anisocytosis and bird's eye cells formation became more prominent. In advanced cases, cellular detritus was noted abundantly in the cellular sample.

Cytologic observations of early invasive cancer according to the degree of invasion are shown in Table 2. The degree of invasion was classified as follows: up to and inclusine of $1 \mathrm{~mm}$; up to and inclusine of $2 \mathrm{~mm}$, up to and inclusine of $3 \mathrm{~mm}$, and up to and inclusine of $5 \mathrm{~mm}$ growth. The number of cases showing the presence of irregularly distributed chromatin, anisocytosis, and bird's eye cells gradually increased with the extent of invasion. Appearance of cellular detritus also increased with extent of invasion, and tended to increase markedly when the depth of invasion was above $2 \mathrm{~mm}$.

Relationship between malignant cells in deep layer and dysplastic cells appearing in cellular samples of carcinoma in situ, early invasive cancer, and advanced cancer

The ratio of malignant cells in the deep layer (chiefly immature malignant

TABLE 1. Cytologic findings of carcinoma in situ, early invasive cancer and advanced cancer

\begin{tabular}{lccc}
\hline & $\begin{array}{c}\text { Carcinoma in situ } \\
\text { Number of cases } \\
(\%)\end{array}$ & $\begin{array}{c}\text { Early invasive cancer } \\
\text { Number of cases } \\
(\%)\end{array}$ & $\begin{array}{c}\text { Advanced cancer } \\
\text { Number of cases } \\
(\%)\end{array}$ \\
\hline $\begin{array}{l}\text { Cases showing } \\
\text { numerous malignant cells }\end{array}$ & $27(31.4)$ & $60(65.9)$ & $46(92.0)$ \\
$\begin{array}{l}\text { Nuclear chromatin } \\
\text { Hyperchromasia }\end{array}$ & $77(89.5)$ & $91(100)$ & \\
$\quad$ Irregularly distributed & $7(8.1)$ & $38(41.8)$ & $50(100)$ \\
Chromatin pattern & & & $47(94.0)$ \\
$\quad$ Fine reticular & 0 & $1(1.1)$ & 0 \\
Coarse reticular & $9(10.5)$ & $7(7.7)$ & 0 \\
Fine granular & $66(76.7)$ & $57(62.6)$ & $13(26.0)$ \\
Coarse granular & $11(12.8)$ & $21(23.1)$ & $35(70.0)$ \\
Opaque & 0 & $5(5.5)$ & $2(4.0)$ \\
Irregular thickening of & $64(74.4)$ & $86(94.5)$ & $50(100)$ \\
$\quad$ nuclear envelope & $40(46.5)$ & $75(82.4)$ & $50(100)$ \\
Anisocytosis & 0 & $22(24.2)$ & $35(70.0)$ \\
Bird's eye cell or inclusion & & & \\
$\quad$ cell & $7(8.1)$ & $29(31.9)$ & $48(96.0)$ \\
Cellular detritus & 86 & 91 & 50 \\
Total cases & & & \\
\hline
\end{tabular}


TABLE 2. Cytologic observations of early invasive cancer according to the degree of invasion

\begin{tabular}{|c|c|c|c|c|}
\hline & \multicolumn{4}{|c|}{ Depth of invasion } \\
\hline & $\begin{array}{l}\sim 1 \mathrm{~mm} \\
\text { Number of } \\
\text { cases }(\%)\end{array}$ & $\begin{array}{l}\sim 2 \mathrm{~mm} \\
\text { Number of } \\
\text { cases }(\%)\end{array}$ & $\begin{array}{l}\sim 3 \mathrm{~mm} \\
\text { Number of } \\
\text { cases }(\%)\end{array}$ & $\begin{array}{l}\sim 5 \mathrm{~mm} \\
\text { Number of } \\
\text { cases }(\%)\end{array}$ \\
\hline $\begin{array}{l}\text { Cases showing } \\
\text { numerous malignant cells }\end{array}$ & $7(46.7)$ & $23(62.2)$ & $16(76.2)$ & $14(77.8)$ \\
\hline $\begin{array}{l}\text { Nuclear chromatin } \\
\text { Hyperchromasia } \\
\text { Irregularly distributed }\end{array}$ & $\begin{array}{c}15(100) \\
4(26.7)\end{array}$ & $\begin{array}{l}37(100) \\
13(35.1)\end{array}$ & $\begin{array}{l}21(100) \\
9(42.9)\end{array}$ & $\begin{array}{l}18(100) \\
12(66.7)\end{array}$ \\
\hline $\begin{array}{l}\text { Chromatin pattern } \\
\text { Fine reticular } \\
\text { Coarse reticular } \\
\text { Fine granular } \\
\text { Coarse granular } \\
\text { Opaque }\end{array}$ & $\begin{array}{l}0 \\
1(6.7) \\
11(73.3) \\
3(20.0) \\
0\end{array}$ & $\begin{array}{r}0 \\
3(8.1) \\
24(64.9) \\
8(21.6) \\
2(5.4)\end{array}$ & $\begin{array}{r}1(4.8) \\
3(14.3) \\
11(52.4) \\
4(19.0) \\
2(9.5)\end{array}$ & $\begin{array}{l}0 \\
0 \\
11(61.1) \\
6(33.3) \\
1(5.6)\end{array}$ \\
\hline $\begin{array}{l}\text { Irregular thickening of } \\
\text { nuclear envelope }\end{array}$ & $14(93.3)$ & $35(94.6)$ & $19(90.5)$ & $18(100)$ \\
\hline Anisocytosis & $9(60.0)$ & $28(75.7)$ & $20(95.2)$ & $18(100)$ \\
\hline $\begin{array}{l}\text { Bird's eye cell or } \\
\text { inclusion cell }\end{array}$ & $2(13.3)$ & $7(18.9)$ & $4(19.0)$ & $9(50.0)$ \\
\hline Cellular detritus & $2(13.3)$ & $6(16.2)$ & $9(42,9)$ & $12(66.7)$ \\
\hline Total cases & 15 & 37 & 21 & 18 \\
\hline
\end{tabular}

cells) to the number of malignant cells in the entire layer was about $81 \%$ in carcinoma in situ, about $61 \%$ in early invasive cancer, and about $55 \%$ in advanced cancer.

On the other hand, the number of cases showing $80 \%$ in the ratio of malignant cells in the deep layer to those in the entire layer was 62 cases (72\%), 28 cases $(31 \%)$, and 10 cases $(20 \%)$, respectively.

The ratio of malignant cells to the sum of malignant and dysplastic cells was about $50 \%$ in carcinoma in situ, about $75 \%$ in early invasive cancer, and about $92 \%$ in advanced cancer. The ratio of dysplastic cells in the deep layer to those in the entire layer was about $36 \%$ in carcinoma in situ, $25 \%$ in early invasive cancer, and $17 \%$ in advanced cancer.

\section{Discussion}

Uterine cervical cancer and carcinoma in situ can be detected in $98.5 \%$ of cervical samples obtained by cervical scrapings with a wooden spatula (Noda et al. 1968). The number of malignant cells recovered in a single preparation depends on the extent of the lesion. If the extent of this lesion is circular in the cervix and is extended towards the vertical axis, the number of malignant cells that appear in the cellular sample will be larger (Masubuchi et al. 1967; Hashimoto et al. 1972; Sugimori 1972). On the other hand, extension of the lesion depends on the 
degree of cancer invasion. When the invasion is less than $3 \mathrm{~mm}$, in about $50 \%$ of the cases the lesion will be limited to below the semicircle of the cervix. This number will be below $25 \%$ when the invasion is 3 to $5 \mathrm{~mm}$, and about $55 \%$ of the cases will have the lesion all around the cervix (Sato 1974). Thus, the extent of invasion is proportional to the number of malignant cells in the preparation.

Hyperchromasia is thought to be one of the prime criteria in the screening of malignant cell nuclei. In fact, its presence was observed in all the cases of carcinoma in situ, early invasive cancer, and advanced cancer. Chromatin structures mostly occur in fine or coarse granular forms. As the invasion progresses, cases of coarse granular chromatin increase, and, at the same time, irregular chromatin distribution is found ( $\mathrm{Ng}$ et al. 1972).

Findings have been reported on the correlation between the extent of cervical cancer and degree of maturity of malignant cells which appeared in cervical samples (Skapier 1949; Kern 1962; Wagner and Schlaich 1965; Minei 1968). Researchers attempted morphologic classifications of these cells (Reagan et al. 1953, 1962; Wied 1956; Reagan and Hamonic 1956; Wied et al. 1962; Tweeddale et al. 1969). It has been found from our results that malignant cells appear in the deep layer of carcinoma in situ, and the ratio of mature malignant cells increases as the lesion progresses from early invasive to advanced cancer. At the same time, there is an increasing number of cases showing great variety of cell types, culminating in bizarre cells.

Moreover, there is a relative increase in the number of malignant to dysplastic cells with the progress of cancer. The same phenomenon was pointed out in other reports (Wied 1956; Tsakiris-Coutifaris 1967; Minei 1968; Kurihara 1972). Regarding dysplastic cells, the less mature types are more numerous in carcinoma in situ. Dysplastic cells of the intermediate or superficial types increase with the advance of cancer.

\section{References}

I) Hashimoto, T., Arata, T., Okazaki, Y. \& Miyamoto, K. (1972) Cytology of dysplasia, carcinoma in situ and micro-invasive carcinoma of the cervix uteri. J. Jap. Soc. clin. Cytol., 11, 289. (Japanese with English abstract)

2) Kern, G. (1962) Cytologische Vorhersage von Epithelatypien an der Cervix uteri. Arch. Gynäk., 197, 314-350.

3) Kurihara, S. (1972) Studies on precancerous lesion of the uterine cervix. Acta obstet. gynaec. jap., 24, 663-672. (Japanese with English abstract)

4) Masubuchi, K., Tenjin, Y., Mihara, H., Aoki, H. \& Yamazaki, M. (1967) The relations between the area of carcinoma in situ of the uterine cervix and its exfoliative malignant cells. J. Jap. Soc. clin. Cytol., 6, 4-5. (Japanese with English abstract)

5) Minei, K. (1968) Cytological findings of early invasive cancer of uterine cervix and its related lesions. Proceedings Obstet. Gynec., 20, 333-349. (Japanese with English abstract)

6) Ng, A.B.P., Reagan, J.W. \& Lindner, E.A. (1972) The cellular manifestations of microinvasive squamous cell carcinoma of the uterine cervix. Acta cytol., 16, 5-13.

7) Noda, K., Sato, S., Higashiiwai, H., Kaneta, N., Nagai, H., Makita, M., Furuya, T., Noda, T., Sai, Y., Tokunaga, M., Sato, H. \& Kato, T. (1968) On the mass population screening of cervical carcinoma in Miyagi Prefecture. Acta obstet. gynaec. 
jap., 20, 1562-1568. (Japanese with English abstract)

8) Reagan, J.W. \& Hamonic, M.J. (1956) The cellular pathology in carcinoma in situ A cytohistopathological correlation - . Cancer, 9, 385-402.

9) Reagan, J.W., Seidemann, I.L. \& Saracusa, Y. (1953) The cellular morphology of carcinoma in situ and dysplasia or atypical hyperplasia of the uterine cervix. Cancer, 6, 224-235.

10) Reagan, J.W., Seidemann, I.B. \& Patten, S.F. (1962) Developmental stages of in situ carcinoma in uterine cervix: An analytical study of the cell. Acta cytol., 6, 538546.

11) Sato, S. (1974) The clinical and histopathological studies on early invasive cancer of the uterine cervix. Acta obstet. gynaec. jap., 26, 629-636. (Japanese with English abstract)

12) Skapier, J. (1949) Diagnosis of preinvasive carcinoma of cervix. Surg. Gynec. Obstet., $89,405-410$.

13) Sugimori, H. (1972) Cytologic findings of carcinoma in situ and its related lesions. J. Jap. Sac. clin. Cytol., 11, 290. (Japanese)

14) Tsakiris-Coutifaris, L. (1967) Cytological criteria of the intraepithelial (in situ) carcinoma of the uterine cervix. Acta cytol., 11, 25-27.

15) Tweeddale, D.N., Langenbach, S.R., Roddick, J.W. \& Holt, M.L. (1969) The Cytopathology of microinvasive squamous cancer of the cervix uteri. Acta cytol., 13, 447-454.

16) Wagner, D. \& Schlaich, P. (1965) Cytologische Verlaufsbeobachtungen während der Entstehung des Collum-Carcinoms. Arch. Gynäk., 200, 610-632.

17) Wied, G.L. (1956) The potentialities of the smear technique for the differentiation of noninvasive and invasive cervical carcinoma. Amer. J. Obstet. Gynec., 71, 793-805.

18) Wied, G.L., Legorreta, G., Mohr, D. \& Rauzy, A. (1962) Cytology of invasive cervical carcinoma and carcinoma in situ. Ann. N.Y. Acad. Sci., 97, 759-766. 